\title{
Structural Transformation in Out-put in J\&K State Economy (1981-2011)
}

\author{
Bilal Ahmad Sheikh \\ Research Scholar (Ph.D), Department of Economics, University of Kashmir
}

\begin{abstract}
The structural change theory states that as GDP per capita increases, the \% share of out-put in primary sector declines whereas the \% share of the secondary sector initially increases and subsequently decreases, while the \% share of tertiary sector increases steadily. The structural change in out-put across Jammu \& Kashmir economy's key sectors is not following the path way of the structural change theory of output which implies that percentage share of out-put in primary sector declines systematically as GNP per capita income rises whereas the percentage share of both secondary and tertiary sectors out-put rise to offset this decline. But, this offset takes place in such a manner that at first stage of structural change theory, major percentage share of out-put reallocates to secondary sector (almost $75 \%$ ) and the rest is reallocated to tertiary sector and during the second stage of structural change theory of out-put, shift of out-put from primary and secondary sector takes place to tertiary sector.
\end{abstract}

Keywords: Key sectors, Structural Transformation theory of Out-put, Structural Change Index (SCI), Linking Factor Method, growth rates

\section{Introduction}

The structural change in output and employment are considered to be important indicators to measure the economic performance of the economy. The sectoral composition of output and employment are the most crucial indicators to measure the contribution of the different sectors of the state economy. One of the best known characteristics of output and labour in developing economies is that most output comes from primary sector and most labour force work in the same sector. Primary sector's share of output and employment is highest in the poorest economies and declines systematically as GNP per capita rises. The shares of both secondary and tertiary sectors' output and employment rise to offset this decline. But, during the first stage of the structural change theory, most resources shifted from primary to secondary sector and then finally in the second stage of the structural change theory resources shifted from both primary and the secondary sectors to the tertiary sector of the economy. There happens inter-sectoral equality in case of output and employment among the three main sectors of the economy. The concept of inter-sectoral equality refers that all the three main sectors contribution in terms of output and employment are the same. The inter-sectoral equality is the indication of the absences of disguised unemployment among the key sectors of the economy. In simple words, it is believed by the structural economists that inter-sectoral equality in terms of output and employment between the three key sectors of the economy is the important indicator to check the overall health of the state economy as it depicts the equality in productivity and income of an economy.

\section{Objectives}

Some of the explicit objectives of the study are as under:

1. To analyze the changes in growth rates and composition of output in the key sectors sectors of the state economy.

2. To examine whether Jammu \& Kashmir follows the out-put path of standard structural transformation theory of out-put.

\section{Data and Methodology}

The study is primarily based on the secondary data that is obtained from the following sources:

- Economic census, Government of India, various issues.

- Digest of statistics; Directorate of Economics and Statistics; Government of J\&K, various issues.

- Economic Survey; Directorate of Economics and Statistics; Government of J\&K, various issues.

- Economic Review of J\&K; Directorate of Economics and Statistics; Government of J\&K, 2007-08.

- Reports, journals, magazines and news papers.

In addition to the above sources relevant information has been collected from the following departments:

- Directorate of Economics, Statistics \& planning, Government of Jammu and Kashmir, Srinagar.

- Directorate of Sericulture, J\&K, Srinagar. 
- Directorate of Handicrafts, J\&K, Srinagar.

- Directorate of Handlooms, J\&K, Srinagar.

- Labour Commissioner, J\&K, Srinagar.

- Financial Commissioner (Rev), J\&K, Srinagar.

- D.F.O Forest Statics Division, Srinagar

- Directorates of Animal Husbandry, J\&K, Srinagar.

- Development Commission of Power, J\&K, Srinagar.

The following appropriate statistical tools have been used to analyze the data:

1) Linking Factor Method: It is a method through which base year is changed or rebase is formed .It is simply done by using the following two formulas:

a) Deflator $=($ Factor $) \times($ Out-put level of the corresponding year $)$

Whereas; $\quad$ Factor $=($ Old Base $) \div($ New Base $)$

b) Inflator $=($ Factor $) \times($ Out-put level of the corresponding year $)$

Whereas; Factor $=($ New Base $) \div($ Old Base $)$

\section{2) Structural Change Index Method}

A commonly used method of measuring structural change in out-put (and employment) is the rate or coefficient of (compositional) structural change, often referred to as a SCI. The SCI for out-put may be defined as half the sum of the absolute value of the differences in value-added over time. The calculation is given by the formula:

$$
\mathrm{SCI}=1 / 2 \sum\left|\mathrm{x}_{\mathrm{i}(\mathrm{t})}-\mathrm{X}_{\mathrm{i}(\mathrm{t}-1)}\right|
$$

Where $X_{i,(t)}$ and $X_{i,(t-1)}$ represent each industry's share of total value added at time $(t)$ and $(t-1)$, respectively. The use of absolute values ensures that positive and negative changes in industry share do not cancel each other out when the values are summed across industries. The SCI is bound between zero and 100, with zero representing no structural change while 100 indicates a complete reversal of structural change.

3) Growth Rate: Simple, average and compound growth rates have been calculated with the help of the following formulas:

a) Annual Growth Rate or Simple Growth Rate: The annual growth rates for a series of $\mathrm{T}$ annual observations, say $\mathrm{y}_{1}, \mathrm{y}_{2}, \mathrm{y}_{3}, \ldots \mathrm{y}_{\mathrm{t}}$ is defined as:

Whereas; $y_{t}$ refers current year out-put

$$
a_{t}=\frac{y_{t}-y_{t-1}}{y_{t}-1}
$$

$\mathrm{y}_{\mathrm{t}-1}$ refers previous year out-put

b) Average Annual Growth Rate: The average growth rate has been calculated with the help of following formula:

Average Annual Growth Rate $=(1 / \mathrm{T})^{*} \mathrm{Ln}\left(\mathrm{Y}_{\mathrm{t}} / \mathrm{Yi}\right)^{*} 100$

Whereas; T refers number of times we see increase or decrease over the time period.

$\mathrm{Ln}$ is the natural logarithm

$\mathrm{Y}_{\mathrm{t}}$ refers variable in final time period

Yi refers variable in initial time period

c) Compound Growth Rate: the compound growth rate (cgr) has been calculated with the help of exponential function which is as:

Exponential function $\quad \mathrm{y}=\mathrm{ab}$

The compound growth rate $=(\mathrm{b}-1)^{*} 100$

\section{Performance of State Economy}

Table-1 shows the absolute sectoral share in NSDP. At current prices, in 1980-81 the contribution of NSDP was Rs. 1051.93 crores which increased to Rs.43716.38 crores in 2010-11, showing an increase of 41.56 times while as at constant prices (at 1993-94 prices), in 1980-81, the absolute contribution of NSDP was Rs. 3793.52 crores which increased to Rs. 17380.16 crores in 2010-11, showing an increase of 4.58 times

As primary sector contributed the bulk share to the NSDP at both prices. It contributed $47 \%$ to NSDP in 1980-81, its percentage share however fell down to $21.98 \%$ in 2010-11(i.e. 25.02 per cent points decrement or 2.14 times decline) at constant prices and at current prices to NSDP its percentage share declined from $47.29 \%$ to $21.1 \%$ (i.e 26.19 per cent points decrement) during the same time period whereas at present the maximum contribution to NSDP is by the Tertiary sector at both prices of the state economy. The contribution of the secondary sector has improved also (refer to Table 2).

Table-3 shows per capita income of state economy in Rs. At constant prices (at 1993-94 prices), in 1980-81, total NSDP per capita income of J\&K state was Rs. 6419 which increased to Rs.14907 in 2010-11, 
showing an increase of Rs. 8488 (i.e. 2.32 times) while as at current prices, in 1980-81, total NSDP per capita income of J\&K state was Rs. 1780 which increased to Rs.37496 in 2010-11, showing an increase of Rs.35716 (i.e.21.07 times).

During the first five year of reference time period, Average Annual Growth Rate of NSDP was 12.13 per cent at current prices which decreased to 8.21 per cent during the second five year. However, during the third five year time period, average annual growth rate improved to 17.49 per cent which is the maximum growth rate during the reference time period. The average annual growth rate decreased continuously from the forth five years time period. It decreased to 14.4 percent during the fourth five year to 11.35 percent in fifth five year and finally 10.96 percent during the sixth five year of the reference time period whereas at constant prices it was 3.17 percent during the first five year and it reached to maximum level during the fifth five year i.e. 9.85 percent, but during the last five year it decreased to 6.92 percent ( refer to Table-4)

The average annual growth (decadal) at current prices reached to maximum level during the second decade (i.e. 15.95 percent) and finally it slumped down to 11.15 percent during the last and the final decade of the reference time period whereas at constant prices it has increased continuously from $2.59 \%$ to $4.25 \%$ and finally to $8.38 \%$ in the respective three decades of the reference period (refer to Table 5)

The average annual growth rate (30-yearly) of NSDP at current prices was 12.42 whereas at constant prices it was 5.07 percent for the entire reference time period (refer to table-6)

The compound growth rate of NSDP at current prices was 10.81 percent for the first decade while it reached to maximum level during the second decade (i.e. 18.15 percent) and finally it slumped down to 11.95 percent during the last and the final decade of the reference time period whereas at constant prices it increased continuously from $2.16 \%$ in to $9.49 \%$ from first to last decade of the reference period (refer to Table-.1.1)

The compound growth rate of primary sector in NSDP at current prices was 13.77 percent whereas at constant prices it was $5.07 \%$ for the entire reference time period (refer to Table-1.2)

Table-1.1: Compound growth rate of NSDP (10-yearly)

\begin{tabular}{|c|c|c|c|c|c|c|c|c|}
\hline \multirow{2}{*}{ Year } & \multicolumn{2}{|c|}{ Primary Sector } & \multicolumn{2}{c|}{ Secondary Sector } & \multicolumn{2}{|c|}{ Tertiary Sector } & \multicolumn{2}{c|}{ NSDP } \\
\cline { 2 - 9 } & Cn.Pr & Ct.Pr & Cn.Pr & Ct.Pr & Cn.Pr & Ct.Pr & Cn.Pr & Ct.Pr \\
\hline $1980-81$ to $1990-91$ & -0.33 & 8.68 & 5.44 & 12.24 & 3.57 & 12.57 & 2.16 & 10.81 \\
\hline $1990-91$ to 2000-01 & 3.38 & 14.95 & 5.3 & 24.17 & 5.25 & 18.92 & 4.62 & 18.15 \\
\hline 2000-01 to 2010-11 & 5.15 & 6.74 & 13.94 & 16.82 & 9.95 & 12.57 & 9.49 & 11.95 \\
\hline
\end{tabular}

Sources: based on Table 7.2

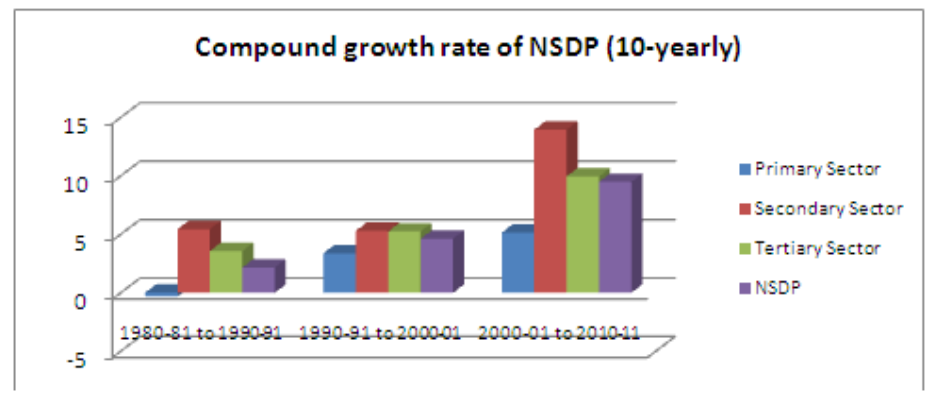

Table 1.2: Compound Growth Rate OF NSDP (30-yearly)

\begin{tabular}{|c|c|c|c|c|c|c|c|c|}
\hline \multirow{2}{*}{ Year } & \multicolumn{2}{|c|}{ Primary Sector } & \multicolumn{2}{|c|}{ Secondary Sector } & \multicolumn{2}{|c|}{ Tertiary Sector } & \multicolumn{2}{|c|}{ NSDP } \\
\cline { 2 - 9 } & Cn.Pr & Ct.Pr & Cn.Pr & Ct.Pr & Cn.Pr.Pr & Ct.Pr & Cn.Pr & Ct.Pr \\
\hline $1980-81$ to $2010-11$ & 3.02 & 11.24 & 7.78 & 17.26 & 5.49 & 14.25 & 5.07 & 13.77 \\
\hline
\end{tabular}

Sources: based on Table 7.2

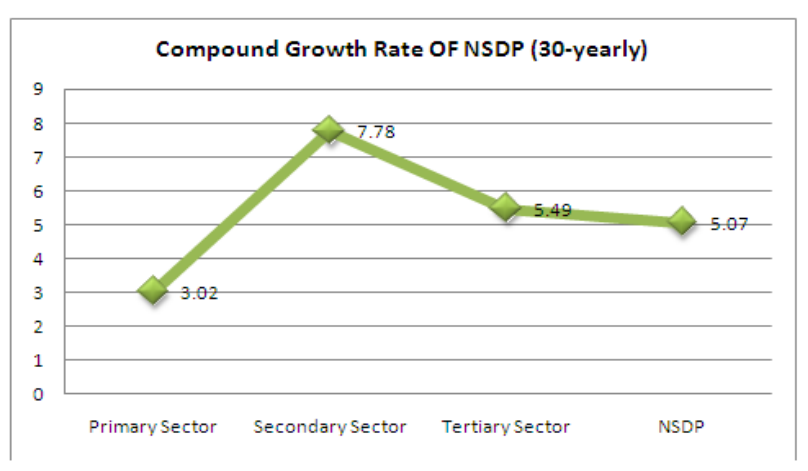


Table 1.3: Relationship between Growth Rate and Structural change (1981 to 2011)

\begin{tabular}{|c|c|c|c|}
\hline $\begin{array}{c}\text { Growth rate of NSDP at } \\
\text { constant prices }\end{array}$ & $\begin{array}{c}\text { Structural change } \\
\text { magnitude }\end{array}$ & $\begin{array}{c}\text { Nature of change } \\
\text { Or shift }\end{array}$ & $\begin{array}{c}\text { Matching with structural } \\
\text { change theory }\end{array}$ \\
\hline 2.59 & 8.93 & $\begin{array}{l}\mathrm{P} \rightarrow \mathrm{S}=43.90 \% \\
\mathrm{P} \rightarrow \mathrm{T}=56.10 \%\end{array}$ & Lesser extent \\
\hline 4.25 & 5.89 & $\begin{array}{l}\mathrm{P} \rightarrow \mathrm{S}=57.89 \% \\
\mathrm{P} \rightarrow \mathrm{T}=42.11 \%\end{array}$ & Greater extent \\
\hline 8.38 & 10.6 & $\begin{array}{l}\mathrm{P} \rightarrow \mathrm{S}=51.89 \% \\
\mathrm{P} \rightarrow \mathrm{T}=48.11 \%\end{array}$ & Great extent \\
\hline
\end{tabular}

Sources: Computed on the basis of data given in table $7.3 \& 7.8$

Note: Growth rate is Decadal Compound Growth rate of NSDP at constant prices.

$\mathrm{P}=$ primary sector; $\mathrm{S}=$ Secondary Sector; $\mathrm{T}=$ Tertiary Sector

From the above table it becomes clear that that structural change and growth rate are positively related to each other $(\mathrm{r}=56 \%)$. During the first decade of the reference period the structural change is equal $8.93 \%$ and growth rate is equal to $2.59 \%$, but the change is matching to the lesser extent to the structural change theory whereas in the second decade of the reference period the structural change is equal to $5.89 \%$ which is lesser than the structural change in the first decade, but the growth rate is higher than the first decade (i.e. $4.25 \%$ ) this is because the structural change in the decade is matching to the maximum extent to the structural change theory. Similarly, in the third decade of the reference period the structural change is equal to $10.6 \%$ whereas the growth rate during the same period is $8.38 \%$ which is maximum and it is maximum because it too matches to the structural change theory to the great extent.

Table 1.4: Output Structural shifts in Key Sectors of J\&K Economy (NSDP at constant prices)

\begin{tabular}{|l|c|c|c|c|}
\hline Sector & $\mathbf{1 9 8 0 - 8 1}$ & $\mathbf{2 0 1 0 - 1 1}$ & Change in \%pt. & SCI $=1 / 2 \sum\left|\mathbf{x}_{\mathbf{i}(\mathbf{t})}-\mathbf{x}_{\mathbf{i}(\mathbf{t}-\mathbf{1})}\right|$ \\
\hline Primary & 47.4 & 21.98 & -25.42 & \multirow{2}{*}{$\mathbf{2}$} \\
\cline { 1 - 4 } Secondary & 12.9 & 25.76 & 12.86 & \multirow{2}{*}{} \\
\hline Tertiary & 39.7 & 52.26 & 12.56 & \\
\hline Total & 100 & 100 & 0 & \\
\hline
\end{tabular}

Sources:

Compiled from:

a) Digest of Statistics, Directorate of Economics and Statistics, J\&K Government, various issues.

b) State Domestic Product, Directorate of Economics and Statistics, J\&K Government, (1980-81 to 1996-97).

c) State Domestic Product, Directorate of Economics and Statistics, J\&K Government, (1993-94 to 1998-99)

d) The Economy of Jammu and Kashmir by Jasbir Singh.

e) Note: Constant prices at 1993-94 which has been calculated by Linking Factor Method.

f) Output Structural shifts in Key Sectors of J\&K Economy is 30-yearly

The above table depicts that structural change across three key sector of Jammu and Kashmir economy is equal to 25.42 percent which implies that during the 30 -year period, The resources shifted from primary sector to secondary sector is equal to 12.86 percent(i.e.50.59\% ) whereas from primary sector to tertiary sector it is equal to 12.56 percent( i.e. $49.41 \%$ ). Therefore, it becomes clear that the structural change of output for the entire reference period is not matching the structural change theory of output that is why growth rate of the economy is not improving.

\section{Conclusion:}

Therefore, it becomes clear that the structural change in output in all the three decades across its key sectors is not following the path way of the structural change theory of output which implies that percentage share of output in primary sector declines systematically as GNP per capita income rises whereas the percentage share of both secondary and tertiary sectors outputs rise to offset this decline. But, this offset takes place in such a manner that at first stage of structural change theory major percentage share of output reallocates to secondary sector (almost 75\%) and the rest is reallocated to tertiary sector and during the second stage of structural change theory of output shift of output from primary and secondary sector takes place to tertiary sector. But, shift from secondary sector takes place after the maturity stage (i.e. after $50 \%$ contribution to economy).

\section{Suggestions}

The research paper makes clear that the growth rate of the J\&K state economy can be improved to the greater extent through following the standard theory of structural transformation of out-put.

The policy makers have to keep in mind that in the first stage of structural transformation theory most of the resources should shift from primary to secondary sector only then the shift provide benefits to economy as has been cleared through the Table-1.3. 
Therefore, the policy makers have to frame the policies through which the secondary sector of the state economy can be made stronger and for that they have to invest in the traditional and the small scall industries segments of the secondary sector as there is a great scope for them to grow there as because of the market availability of the products produced in the traditional and small scale industries sub-sectors even outside the state economy.

The policy makers have to frame the policies for human capital development by simply investing in the human skill formations programmes. As skill formation is the basic incentive to the labour force to keep them engage in economic activities through which shift takes place from 'Leisure liking syndrome to work culture.'

Finally, investment is required for the overall growth and development of the state economy as it is one of the basic principle of the 'Growth Economics' that growth is the function of investment where as investment by itself is the function of peace or political stability which is not present in the state economy. Therefore, policy makers at both state and central level have to frame such policies through which peace can be improved in the state economy.

\section{Appendix}

Table 1: Sectoral NSDP at constant and current Prices (Rs. crores)

\begin{tabular}{|c|c|c|c|c|c|c|c|c|}
\hline \multirow{2}{*}{ Year } & \multicolumn{2}{|c|}{ Primary Sector } & \multicolumn{2}{|c|}{ Secondary Sector } & \multicolumn{2}{|c|}{ Tertiary Sector } & \multicolumn{2}{|c|}{ NSDP } \\
\hline & Cn.Prices & Ct.Prices & Cn.Prices & Ct.Prices & Cn.Prices & Ct.Prices & Cn.Prices & Ct.Prices \\
\hline 1985-86 & 1993.38 & 794.61 & 666.82 & 321.97 & 1785.18 & 812.65 & 4445.38 & 1929.23 \\
\hline 1995-96 & 2387.08 & 2653.73 & 908.25 & 1161.03 & 2736.15 & 3158.29 & 6031.48 & 6973.05 \\
\hline $2000-01$ & 2448.58 & 4729.5 & 1520.45 & 2914.55 & 3546.42 & 6684.35 & 7515.45 & 14328.4 \\
\hline $2005-06$ & 3775 & 7339.08 & 3657.52 & 7138.37 & 4864.73 & 10800.65 & 12297.25 & 25278.1 \\
\hline
\end{tabular}

Sources:

\section{Compiled from:}

a) Digest of Statistics, Directorate of Economics and Statistics, J\&K Government, various issues.

b) State Domestic Product, Directorate of Economics and Statistics, J\&K Government, (1980-81 to 1996-97).

c) State Domestic Product, Directorate of Economics and Statistics, J\&K Government, (1993-94 to 1998-99).

d) The Economy of Jammu and Kashmir by Jasbir Singh.

e) Note: Constant prices at 1993-94 which has been calculated by Linking Factor Method.

i) Cn. $=$ Constant, ) i Ct. $=$ Current

Table 2: Sectoral NSDP at constant and current Price (in percentages)

Sources: based on Table 1

\begin{tabular}{|c|c|c|c|c|c|c|c|c|}
\hline \multirow{2}{*}{$\begin{array}{l}\text { Ye } \\
\text { ar }\end{array}$} & \multicolumn{2}{|c|}{ Primary Sector } & \multicolumn{2}{|c|}{$\begin{array}{c}\text { Secondary } \\
\text { Sector }\end{array}$} & \multicolumn{2}{|c|}{ Tertiary Sector } & \multicolumn{2}{|c|}{ NSDP } \\
\hline & $\begin{array}{c}\text { Cn.Pr } \\
\text { ices }\end{array}$ & $\begin{array}{c}\text { Ct.Pr } \\
\text { ices }\end{array}$ & $\begin{array}{c}\text { Cn.Pr } \\
\text { ices }\end{array}$ & $\begin{array}{c}\text { Ct.Pr } \\
\text { ices }\end{array}$ & $\begin{array}{c}\text { Cn.Pr } \\
\text { ices }\end{array}$ & $\begin{array}{c}\text { Ct.Pr } \\
\text { ices }\end{array}$ & $\begin{array}{c}\text { Cn.Pr } \\
\text { ices }\end{array}$ & $\begin{array}{c}\text { Ct.Pr } \\
\text { ices }\end{array}$ \\
\hline $\bar{\infty}$ & 47 & 47.29 & 12.9 & 13.1 & 39.7 & 39.61 & 100 & 100 \\
\hline$\infty$ & 44.84 & 41.19 & 15 & 16.69 & 40.16 & 42.12 & 100 & 100 \\
\hline $\bar{\sigma}$ & 38.47 & 43.29 & 16.81 & 13.22 & 44.71 & 43.49 & 100 & 100 \\
\hline 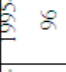 & 39.58 & 38.06 & 15.06 & 16.65 & 45.36 & 45.29 & 100 & 100 \\
\hline 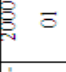 & 32.58 & 33.01 & 20.23 & 20.34 & 47.19 & 46.65 & 100 & 100 \\
\hline 8 & 30.7 & 29.03 & 29.74 & 28.24 & 39.56 & 42.73 & 100 & 100 \\
\hline$=$ & & & & 28.94 & 26 & 49.95 & 100 & 100 \\
\hline
\end{tabular}

Table 3: Per capita income of Macro Sectors of J\&K Economy in NSDP (in Rs.) 


\begin{tabular}{|c|c|c|c|c|c|c|c|c|}
\hline \multirow{2}{*}{ 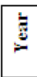 } & \multicolumn{2}{|c|}{ Primary Sector } & \multicolumn{2}{|c|}{ Secondary Sector } & \multicolumn{2}{|c|}{ Tertiary Sector } & \multicolumn{2}{|c|}{ NSDP } \\
\hline & Cn.Prices & Ct.Prices & Cn.Prices & Ct.Prices & Cn.Prices & Ct.Prices & Cn.Prices & Ct.Prices \\
\hline $\begin{array}{l}\bar{\infty} \\
\dot{\mathscr{\alpha}} \\
\stackrel{\varrho}{-}\end{array}$ & 3042.37 & 841.69 & 828.12 & 233.21 & 2548.32 & 705.01 & 6418.82 & 1779.91 \\
\hline $\begin{array}{l}\dot{\infty} \\
\ddot{\infty} \\
\mathscr{2}\end{array}$ & 2969.43 & 1183.69 & 993.33 & 479.62 & 2659.29 & 1210.56 & 6622.05 & 2873.87 \\
\hline 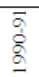 & 2480.15 & 1651.65 & 1084.05 & 504.54 & 2882.48 & 1659.42 & 6446.68 & 3815.61 \\
\hline 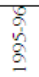 & 2664.45 & 2962.08 & 1013.79 & 1295.94 & 3054.08 & 3525.27 & 6732.31 & 7783.29 \\
\hline $\begin{array}{l}\overline{8} \\
8 \\
8 \\
\stackrel{1}{\circ}\end{array}$ & 2438.34 & 4709.72 & 1514.09 & 2902.36 & 3531.59 & 6656.39 & 7484.02 & 14268.47 \\
\hline 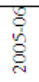 & 3470.63 & 6747.34 & 3362.62 & 6562.81 & 4472.49 & 9929.81 & 11305.74 & 23239.96 \\
\hline$\frac{\bar{c}}{\frac{1}{\rho}}$ & 3276.22 & 7913.18 & 3839.89 & 10852.47 & 7790.97 & 18730.17 & 14907.08 & 37495.82 \\
\hline
\end{tabular}

Sources: based on Table 1

Table 4: Percentage of Average Annual Growth Rate of NSDP (5-yearly)

\begin{tabular}{|c|c|c|c|c|c|c|c|c|}
\hline \multirow{2}{*}{ 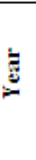 } & \multicolumn{2}{|c|}{ E } & \multicolumn{2}{|c|}{$\begin{array}{l}\text { Secondary } \\
\text { Sector }\end{array}$} & \multicolumn{2}{|c|}{ Tertiary Sector } & \multicolumn{2}{|c|}{ NSDP } \\
\hline & $\begin{array}{c}\text { Cn.Pr } \\
\text { ices }\end{array}$ & $\begin{array}{l}\text { Ct.Pr } \\
\text { ices }\end{array}$ & $\begin{array}{c}\text { Cn.Pr } \\
\text { ices }\end{array}$ & $\begin{array}{l}\text { Ct.Pr } \\
\text { ices }\end{array}$ & $\begin{array}{l}\text { Cn.Pr } \\
\text { ices }\end{array}$ & $\begin{array}{l}\text { Ct.Pr } \\
\text { ices }\end{array}$ & $\begin{array}{c}\text { Cn.Pr } \\
\text { ices }\end{array}$ & $\begin{array}{r}\text { Ct.Pr } \\
\text { ices }\end{array}$ \\
\hline 9 & 2.06 & 9.37 & 6.19 & 16.97 & 3.4 & 13.36 & 3.17 & 12.13 \\
\hline$\frac{\delta}{\stackrel{\delta}{\varrho}}$ & -1.06 & 9.2 & 4.29 & 3.55 & 4.15 & 8.85 & 2 & 8.21 \\
\hline$\frac{\hat{\sigma}}{\hat{\Omega}}$ & 4.67 & 14.9 & 1.89 & 22.1 & 4.39 & 18.3 & 4.1 & 17.49 \\
\hline 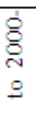 & 0.51 & 11.56 & 10.3 & 18.41 & 5.19 & 14.99 & 4.4 & 14.4 \\
\hline 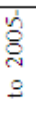 & 8.66 & 8.79 & 17.56 & 17.92 & 6.32 & 9.6 & 9.85 & 11.35 \\
\hline $\begin{array}{l}\frac{d}{\circ} \\
\stackrel{ᄋ}{9}\end{array}$ & 0.24 & 4.58 & 4.04 & 11.45 & 12.49 & 14.08 & 6.92 & 10.96 \\
\hline
\end{tabular}

Sources: based on Table 1

Table 5: Percentage of Average Annual Growth Rate of NSDP (10-yearly) 


\begin{tabular}{|c|c|c|c|c|c|c|c|c|}
\hline \multirow{2}{*}{ Year } & \multicolumn{2}{|c|}{ Primary Sector } & \multicolumn{2}{|c|}{ Secondary Sector } & \multicolumn{2}{|c|}{ Tertiary Sector } & \multicolumn{2}{|c|}{ NSDP } \\
\hline & Cn.Prices & Ct.Prices & Cn.Prices & Ct.Prices & Cn.Prices & Ct.Prices & Cn.Prices & Ct.Prices \\
\hline 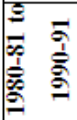 & 0.5 & 9.29 & 5.24 & 10.26 & 3.78 & 11.1 & 2.59 & 10.17 \\
\hline 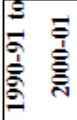 & 2.59 & 13.24 & 6.1 & 20.25 & 4.79 & 16.65 & 4.25 & 15.95 \\
\hline 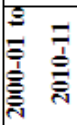 & 4.45 & 6.68 & 10.8 & 14.68 & 9.41 & 11.84 & 8.38 & 11.15 \\
\hline
\end{tabular}

Sources: based on Table 1

Table 6: Percentage of Average Annual Growth Rate of NSDP (30-yearly)

\begin{tabular}{|c|c|c|c|c|c|c|c|c|}
\hline \multirow{2}{*}{ Year } & \multicolumn{2}{|c|}{ Primary Sector } & \multicolumn{2}{|c|}{ Secondary Sector } & \multicolumn{2}{c|}{ Tertiary Sector } & \multicolumn{2}{c|}{ NSDP } \\
\cline { 2 - 9 } & Cn.Pr & Ct.Pr & Cn.Pr & Ct.Pr & Cn.Pr & Ct.Pr & Cn.Pr & Ct.Pr \\
\hline $1980-81$ to 2010-11 & 2.51 & 9.73 & 7.38 & 15.07 & 5.99 & 13.2 & 5.07 & 12.42 \\
\hline
\end{tabular}

Sources: based on Table 1

[1]. Economic census, Govt. of India, various issues.

\section{References}

[2]. Digest of statistics; Directorate of Economics and Statistics; Govt. of J\&K, various issues

[3]. Economic Survey; Directorate of Economics and Statistics; Govt. of J\&K, various issues.

[4]. Economic Review of J\&K; Directorate of Economics and Statistics; Govt. of J\&K, 2007-08

[5]. Strategizing Industrial Development in Jammu and Kashmir, Khursheed A. Butt, 2005.

[6]. $\quad 8^{\text {th }}$ Agriculture Census J \& K State, 2005-06.

[7]. The Economy of Jammu and Kashmir by Jasbir Singh

[8]. Ministry of Agriculture, Government of India, New Delhi

[9]. M.Phil Desertation "Comparative Study of Trends in production and Productivity of Major food Crops in Jammu and Kashmir,Punjab and Himachal Pradesh”, by Naseer Hussain Bazaz, Kashmir university, 2010.

[10]. Reports, journals, magazines and news papers.

[11]. Ayazi, A.R. (1968). Inter relationship between Agriculture and other sector and their implication in terms of planning. Near East Commission on Agricultural Planning.

[12]. Bamzai, P.N.K. (2008). History of Kashmir, Gulshan Publishers Srinagar.

[13]. Beg, M.A. (1951). On the Way of Golden Harvests; Agricultural Reforms in Kashmir, Jammu and Kashmir Government.

[14]. Economic Review of Jammu and Kashmir, (2006-07). Directorate of Economics and Statistics, Planning and Development Department. Govt. of J \& K.

[15]. Gupta, N.S and Sing, A.J. (1979). Agricultural Development of States in India, Vol. I, Jammu and Kashmir.

[16]. Masoodi, M.A: Agriculture in Jammu and Kashmir - A Perspective.

[17]. NCAER. (1969). Techno-Economic survey of J\&K. National council of applied Economic research, New Delhi.

[18]. Nisar, A. (1978). Deteriorationg agrarian situation in Jammu and Kashmir, Easter Econmist.

In addition to the above sources relevant information has been collected from the following departments:

1. Directorate of Economics, Statistics \& planning, Govt. of Jammu and Kashmir, Srinagar.

2. Directorate of Sericulture, J\&K, Srinagar.

3. Directorate of Handicrafts, J\&K, Srinagar.

4. Directorate of Handlooms, J\&K, Srinagar.

5. Labour Commissioner, J\&K, Srinagar.

6. Financial Commissioner (Rev), J\&K, Srinagar.

7. D.F.O Forest Statics Division, Srinagar

8. Directorates of Animal Husbandry, J\&K, Srinagar. 